\title{
7
}

\section{Removal of Selected Benzothiazols with Ozone}

\author{
Jan Derco ${ }^{1}$, Michal Melicher ${ }^{1}$ and Angelika Kassai ${ }^{2}$ \\ ${ }^{1}$ Institute of Chemical and Environmental Engineering, \\ Slovak University of Technology, Bratislava, \\ ${ }^{2}$ Water Research Institute, Bratislava, \\ Slovak Republic
}

\section{Introduction}

Benzothiazole derivatives are widely used as industrial chemicals in the leather and wood industries, as bio-corrosion inhibitors in cooling systems, ingredients in anti-freezing agents for automobiles, and mainly as vulcanisation accelerators in rubber production. Correspondingly, these xenobiotic compounds are widely distributed in the environment and they have been detected in industrial wastewaters, as well as in soils, estuarine sediments, and superficial waters (Valdés \& Zahor, 2006). They cause environmental concern when released into watercourses (Valdés et al., 2008). These compounds inhibit micro-organisms' activity in conventional biological wastewater treatment systems and most of them are not readily biodegradable (de Wewer \& Verachter, 1997; de Wewer, 2007). Moreover, they can be absorbed onto cell membranes, leading to bioaccumulation (Gaja \& Knapp, 1998). According to Knapp et al. (1982), 7.0 mg.l-1 BT causes a 50\% and 54 mg..$^{-1}$ a $100 \%$ inhibition of ammonia oxidation, while nitrate utilization is not affected (de Wever and Verachter, 1997). Tomslino et al. (1966) proved 75\% inhibition of ammonium nitrogen oxidation at the concentration of $3 \mathrm{mg} \cdot \mathrm{l}^{-1} \mathrm{MBT}$. HOBT causes $100 \%$ inhibition of oxidation of ammonium nitrogen at 60 mg.1-1 (Hauck, 1972).

Unfortunately, conventional biological wastewater treatment processes are not able to effectively remove such contaminants since these are resistant to biodegradation (Valdés \& Zahor, 2006). Thus, the development of efficient treatment/pre-treatment processes is required in order to eliminate their discharge into the aquatic ecosystem. Advanced oxidation processes (AOPs) might be a viable option for the decontamination of biologically recalcitrant wastewaters (Kralchevska et al., 2010). An important group of AOPs are ozone based oxidation procesess, e.g. ozonation at elevated $\mathrm{pH}$, combinations of ozone with $\mathrm{UV}$, hydrogen peroxide etc.

Experimental part of this work was focused on the removal of benzothiazole derivatives by ozone. The results of ozonation trials carried out with the model wastewaters containing single MBT and BT pollutants, the mixture of BT and MBT, the mixtuere of benzothiazole derivatives contained in an industrial wastewater from sulfonamides production as well as with the real wastewater are presented. The conventional ozonation process was 
investigated with the aim to decrease the toxicity of selected pollutants to microorganisms of activated sludge.

Reaction kinetics was evaluated for two reasons: firstly for quantification of effect of $\mathrm{pH}$ on degradation of selected pollutants and secondly, for the estimation of kinetic parameters of main pollutants in model wastewater. The kinetic parameters obtained will be used to design the conditions for ozonation process for treatment of real industrial waste water which contains also other components. Obtained results will be applied for process scale up purposes.

The results of two novel ozonation processes are also presented. Zeolite adsorbent was applied in the adsorption ozonation process. Integrated utilisation of ozone for the degradation of MBT in solutions as well as its degradation after the adsorption on activated sludge and simultaneous disintegration/solubilisation of excess sludge in order to minimise its production was also studied.

\section{Mechanisms of ozone oxidation}

Ozone, $\mathrm{O}_{3}$, is a strong oxidant that is able to react through two different reaction mechanisms. Depending on process parameters $(\mathrm{pH})$, the presence of other substances and type/structure of pollutants (Sánchez-Polo et al., 2005) in their molecular (direct reactions of ozone) or hydroxyl radical form (indirect reactions) occur. Molecular ozone is a rather selective oxidant. It can react directly with certain functional groups of organic compounds found in water and wastewaters, such as unsaturated and aromatic hydrocarbons substituted with hydroxyl, methyl and amine groups giving rise to degradation products. Because of this high selectivity, many industrial wastewater treatment oxidation processes can be performed using molecular ozone. On the other hand, ozone decomposes in water to form $\mathrm{OH}$ radicals which are stronger oxidising agents than ozone itself, thus inducing socalled indirect ozonation. Ozone decomposition in water can be initiated by the hydroxyl anion, HO- Indirect ozone oxidation is advanced under alkaline $\mathrm{pH}$ conditions (Hoigne \& Bader, 1976, 1981).

Major limitations of the ozonation process are the relatively high costs of ozone generation processes coupled with the very short half-life period of ozone. Thus, ozone must always be generated at the site. However, maximum concentration of ozone produced in air or oxygen is approximately 4 to $8 \%$, respectively, which is coupled with the very low (5 to $10 \%$ ) energy efficiency of the production and the requirement of an absolutely dry input of air or oxygen. Process efficiency is significantly dependent on efficient gas liquid mass transfer, which is quite difficult to achieve due to the low solubility of ozone in aqueous solutions. Schemes of typical equipments used for ozonation and typical operating parameters were presented by Gogate \& Pandit (2004).

Total mineralisation with ozone is very expensive. Thus, newly developed processes apply ozone only for the elimination of toxic compounds and/or for partial oxidation of resistant wastewater organic pollutants. Controlled ozonation processes which can inactivate inhibitory compounds in wastewater treatment and improve the biodegradability of recalcitrant organics by altering their chemical structure are applied. The extent of this 
partial oxidation needs only to be sufficient to facilitate the subsequent biodegradation of converted organic matter.

Another possibility is to use ozone in combination with other techniques such as Ultrasonic/UV radiation, hydrogen peroxide, or other hybrid methods (Gogate \& Pandit, 2004; Rodrígues 2009). State of the art of AOPs for wastewater treatment was presented by Poyatos et al. (2010).

The attack by the $\mathrm{OH}$ radical, in the presence of oxygen, initiates a complex chain of oxidative reactions leading to mineralisation of the organic compound. The exact mechanism of these reactions is still not quite clear. For example, chlorinated organic compounds are first oxidised to intermediates, such as aldehydes and carboxylic acids, and finally to $\mathrm{CO}_{2}, \mathrm{H}_{2} \mathrm{O}$, and the chloride ion. Nitrogen in organic compounds is usually oxidised to nitrate or free $\mathrm{N}_{2}$, sulphur is oxidised to sulphate (Munter, 2001).

However, the $\mathrm{OH}$ radical also reacted with non-targeted substrates, and, as a result, undesirable by-products were produced in some cases. A novel ozonation process using zeolite adsorbents, adsorptive ozonation, was proposed to solve this problem (Fujita et al., 2004). Organic pollutants and ozone can be adsorbed in micropores. As a result, concentrations in micropores become much higher than those in the bulk phase. Therefore, the apparent reaction rate can be increased.

\section{Applications of ozone based processes for wastewater treatment}

Ozonation can be a suitable technique for the pre-treatment of wastewaters containing low concentrations of toxic or non-biodegradable compounds that cannot be treated with satisfactory results when only traditional, less expensive, biological techniques are applied. In this case, the oxidation process has to be as efficient as possible in order to reduce the costs of ozone addition and energy use. An efficient oxidation process with ozone can be reached by focusing the oxidation with ozone selectively on direct oxidation of toxic pollutants and by minimising ozone loss due to the decay of ozone in water (Boncz et al. 2003).

Applications of ozone techniques for control pollution in full-scale industrial wastewater treatment plants are used in the areas of electroplating wastes, electronic chip manufacture, textiles and petroleum refineries, and treating rubber additive wastewaters (Rice, 1997).

Munter (2001) mentions full scale of ozone applications for decolouration of textile industry wastewaters in several countries and the advantages of ozone and ozone/hydrogen peroxide treatment for the control of microbiological growth in the white water system of the paper machine.

Ozone together with GAC is also efficient considering the solution of environmental problems in the petroleum industry (Munter, 2001).

Because of its high oxidation potential and specific lethality, ozone is the most effective disinfecting agent. When ozone disinfects or breaks down harmful bacteria or pollutants, there are generally no by-products, unlike most other disinfecting agents. Ozone treatment 
has proven to be very effective for complete removal of colour and for detoxifying of textile washing wastewaters treated for reuse. Acceptance of ozone as a replacement bleaching agent to eliminate the discharge of halogenated effluents from pulp bleaching plants is on the rise.

Improvement of the efficiency of organic pollutants removal was observed in combined systems of ozone with adsorption materials. Zeolite is a natural, low cost, and widely available material, and it makes a suitable candidate for heterogeneous ozonation (Valdes et al., 2009).

Applications of chemical oxidation processes including ozone based degradation processes for complete mineralisation of organics are generally expensive. One attractive potential alternative is the application of these processes by pre-treatment converting the initially resistant (toxic, harmful, persistent) organic compounds into more biodegradable intermediates which can then be mineralised in a biological oxidation process. Many studies have shown that biodegradability of organic components in the waste stream is enhanced when subjected to prior chemical oxidation (Oller et al., 2009). For example, the combination of ozone oxidation followed by biological treatment has been installed in full-scale at a large German industrial chemical complex (Fanchiang et al., 2008).

Ozone also supports other processes. In a newly developed system with ozone-resistant membrane, residual ozone prevents membrane fouling and enables high rate water flux in the micro-filtration process. The use of ozone for pre-treatment prior to adsorption of organics by granular activated carbon has extended the useful life of GAC adsorbers before regeneration is required. Although GAC adsorption alone can reach the same results when removing petroleum related compounds from wash waters, the preozonation step not only extends the operational life of GAC but it does so at a lower total cost.

Contrary to the above-stated drawbacks of ozone, a remarkable advantage of ozone and AOPs in comparison to all conventional chemical and biological processes is that they are totally environmentally friendly. They neither transfer pollutants from one phase to the other (as in adsorption, chemical precipitation, coagulation and volatilisation) nor do they produce massive amounts of sludge (as in activated sludge or coagulation processes).

\section{Degradation of benzothiazole derivatives}

A Lifetech ozone generator with maximum ozone production of $5 \mathrm{~g} \mathrm{~h}^{-1}$ was used for all experiments carried out in this work. Ozone was prepared from pure oxygen. The values of other parameters and ozonation reactors used for different experiments are briefly specified in the following text.

\subsection{Materials and methods}

\subsubsection{Characterisation of wastewater}

Model wastewater contained some or all of the following compounds: 2-mercaptobenzothiazole (MBT), benzothiazole (BT), 2-hydroxybezothiazole (OHBT), 
2-aminobenzotiazole (ABT), and aniline (AN) as selected organic pollutants of an industrial wastewater depending on experimental trials. All chemicals were provided by Merck ( $\geq 95.5 \%$ purity).

\subsubsection{Experimental equipment and procedures}

Ozonation experiments were carried out in a lab-scale bubble ozonation column, jet loop ozonation reactor and a completely mixed ozonation reactor.

The ozonation glass columns have a diameter of 0.04 meter and height of $1.7 \mathrm{~m}$. Ozone was produced from oxygen by an ozone generator with maximum production of 5 g.h-1 of ozone. The mixture of oxygen and ozone was injected at the bottom through porous air diffusers with a constant flow rate of $401 . h^{-1}$.

The ozonation column was filled with 1 litre of wastewater. The experiments were carried out with the synthetic wastewater containing $1 \mathrm{~g} . \mathrm{l}^{-1}$ of MBT. The system was operated in the batch mode.

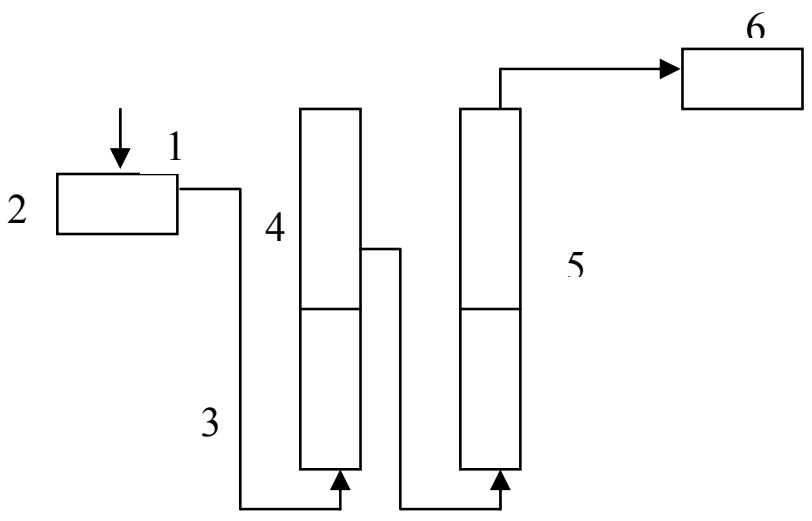

Fig. 1. Scheme of bubble ozonation column

1 - feed of oxygen, 2 - ozone generator, 3 - feed of ozone, 4 - ozonation column with wastewater, 5 - ozonation column with a solution of KI, 6 - destruction of ozone

A scheme of the jet loop ozonation equipment is shown in Figure 2. The system was operated in the batch mode with regard to the wastewater samples. The samples were added into a jet loop ozonation reactor at the beginning of the trials.

A mixture of $\mathrm{O}_{3}$ and $\mathrm{O}_{2}$ was injected into a wastewater sample through a Venturi ejector. At the same time, the ejector sucked the mixture of $\mathrm{O}_{3}$ and $\mathrm{O}_{2}$ from the reactor headspace. This, together with external circulation, should improve the efficiency of ozone utilisation in the ozonation reactor. The outlet gas mixture was conducted into a bubble column through a fine-bubble porous distribution element. The bubble column had $0.04 \mathrm{~m}$ in diameter and $1.7 \mathrm{~m}$ in height. The column was filled with a solution of potassium iodide. The excess ozone destruction was carried out in this column. Similarly to the ozonation reactor, effective volume of the bubble column was $1.0 \mathrm{dm}^{3}$. 
в

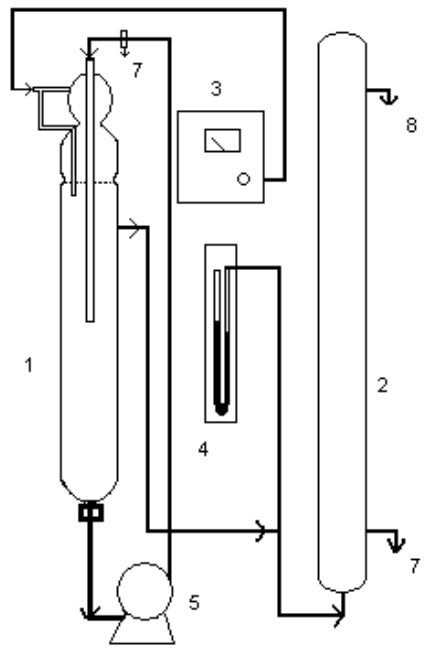

Fig. 2. Scheme of jet loop ozonation equipment

1 - ozonation jet loop reactor, 2 - destruction of excess $\mathrm{O}_{3}, 3$ - ozone generator,

4 - manometer, 5 - pump, 6 - inlet of the mixture of $\mathrm{O}_{3}$ and $\mathrm{O}_{2}, 7$ - sampling, 8 - gas outlet

The continuous flow of oxygen of $20 \mathrm{l} \mathrm{h}^{-1}$ was applied for the generation of ozone. Ozonation trials were carried out at $30 \%$ of the ozone generator's power maximum.

Some experiments were carried out in a batch stirred ozonation reactor (Figure 3) with the reactor volume of $200 \mathrm{ml}$. A magnetic stirrer was used to homogenise the reaction mixture of $100 \mathrm{ml}$ of model wastewater and zeolite (grain size $\mathrm{d}=0.315$ to $0,400 \mathrm{~mm}$ ).

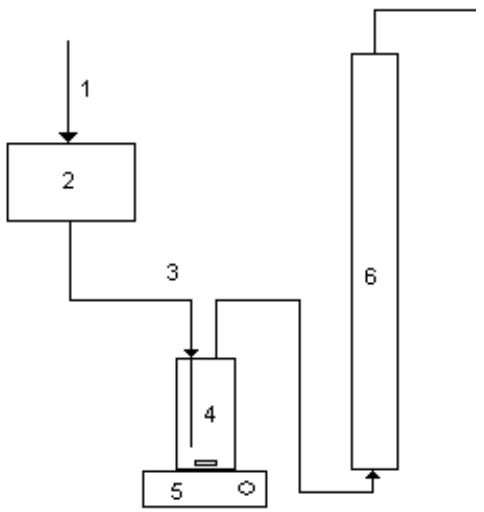

Fig. 3. Scheme of mechanically stirred ozonation reactor

1 - oxygen, 2 - ozone generator, 3 a mixture of $\mathrm{O}_{2}$ and $\mathrm{O}_{3}, 4$ - ozonation reactor 5 - magnetic stirrer, 6 - residual ozone destruction in the KI solution 
The same ozone generator (Lifetech) as in previous experiments using the recirculation reactor (Figure 2) and column apparatus (Figure 1) was used. The flow of oxygen to the ozone generator was maintained at $401 . \mathrm{h}^{-1}$.

The influence of raw and ozonated wastewater samples on the activated sludge microorganisms activity, respirometric measurements (Spanjer et al, 2000) and a nitrification kinetic test were carried out with activated sludge sampled at the industrial wastewater treatment plant.

Specific ozone consumption was evaluated based on the balance of ozone concentration in the influent and effluent gas. A UV detector Life ODU 100 was used to analyse the ozone gas content.

\subsubsection{Analytical procedures}

Analytical control of raw wastewater and monitoring of the treatment procedures included $\mathrm{pH}$, and COD (Chemical Oxygen Demand) determination (ISO 6060, 1989; Greenberg et al, 2005). TOC was measured with analyser Shimdzu TOC-V $V_{C P H / C P N}$ (USA). MBT, BT and their derivatives were analysed using a Hewlett Packard Liquid chromatograph series II 1090 with a DAD detector. The direct injection method was applied using linear gradient of RP-HPLC with a UV-DAD detector on column C18 (Merck).

\subsubsection{Mathematical treatment of experimental data}

Experimental data were fitted by zero (Eq. (1)), first (Eq. (2)), and second (Eq. (3)) order reaction kinetic models. Besides these single power law models, a combined - "two components" (TCM) kinetic model (Eq. (4)) with the first order reaction kinetics was applied to proportions of easily and slowly oxidizable organics. For a batch reaction system, under the assumption of a constant reaction volume, the following relationships were obtained for COD (in general for substrate S)

$$
\begin{gathered}
\mathrm{COD}_{\mathrm{t}}=\mathrm{COD}_{0}-\mathrm{k}_{0} \mathrm{t} \\
\mathrm{COD}_{\mathrm{t}}=\mathrm{COD}_{0} \exp \left(-\mathrm{k}_{1} \mathrm{t}\right) \\
\mathrm{COD}_{\mathrm{t}}=\frac{\mathrm{COD}_{0}}{\left(1+\mathrm{COD}_{0} \mathrm{k}_{2} \mathrm{t}\right)} \\
\mathrm{COD}_{\mathrm{t}}=\mathrm{COD}_{\mathrm{EO}, \mathrm{t}}+\mathrm{COD}_{\mathrm{SO}, \mathrm{t}}=\mathrm{aCOD} \exp \left(-\mathrm{k}_{\mathrm{EO}} \mathrm{t}\right)+(1-\mathrm{a}) \mathrm{COD}_{0} \exp \left(-\mathrm{k}_{\mathrm{SO}} \mathrm{t}\right)
\end{gathered}
$$

where $\mathrm{COD}_{t} /\left(\mathrm{g} \mathrm{m}^{-3}\right)$ denotes the value of $\mathrm{COD}$ in wastewater in time $t, \mathrm{COD}_{0} /\left(\mathrm{g} \mathrm{m}^{-3}\right)$ the initial value of COD in wastewater, $k_{0} /\left(\mathrm{g} \mathrm{m}^{-3} \mathrm{~h}^{-1}\right), k_{1} / \mathrm{h}^{-1}, k_{2} /\left(\mathrm{g}^{-1} \mathrm{~m}^{3} \mathrm{~h}^{-1}\right)$ the rate constants for the zero, first and second order kinetics, respectively, $\mathrm{COD}_{\mathrm{EO}, t} /\left(\mathrm{g} \mathrm{m}^{-3}\right)$ the value of easily oxidizable organics, $\mathrm{COD}_{\mathrm{SO}, t} /\left(\mathrm{g} \mathrm{m}^{-3}\right)$ the value of slowly oxidizable organics, $k_{\mathrm{EO}} / \mathrm{h}^{-1}$ the first order reaction rate constant for easily oxidizable organics, $k_{\mathrm{so}} / \mathrm{h}^{-1}$ the first order reaction rate constant for slowly oxidizable organics, and $a$ the portion of easily oxidizable organics. 
Parameter values of the applied kinetic models were calculated by the grid search optimisation procedure. The residual sum of squares $\left(S_{r}^{2}\right)$ between the observed values and the values given by the model, divided by its number of degrees of freedom $v$ (the number of observations less the number of parameters estimated) was used as the objective function $\left(\mathrm{S}_{\mathrm{r}}^{2}\right)$.

COD reduction by partial oxidation can be done by the following equations (Fiehn et al, 1998):

COD removal in total:

$$
\operatorname{aCOD}_{\mathrm{oxi}}=1-\frac{\mathrm{COD}_{\mathrm{t}}}{\mathrm{COD}_{0}}
$$

COD removal due to mineralisation:

$$
\alpha \mathrm{COD}_{\text {min }}=1-\frac{\mathrm{DOC}_{\mathrm{t}}}{\mathrm{DOC}_{0}}
$$

COD removal due to partial mineralisation:

$$
\alpha \mathrm{COD}_{\text {partoxi }}=\alpha \mathrm{COD}_{\text {oxi }}-\alpha \mathrm{COD}_{\text {min }}
$$

Degree of effectiveness of partial oxidation:

$$
\mu \mathrm{COD}_{\text {partoxi }}=\frac{\alpha \mathrm{COD}_{\text {partoxi }}}{\alpha \mathrm{COD}_{\text {oxi }}}
$$

Ozone transferred in the reactor was calculated by macroscopic mass balance across the reactor:

$$
\mathrm{O}_{3, \text { trans }}=\mathrm{Q}_{\mathrm{g}} \int_{0}^{\mathrm{t}} \frac{\mathrm{O}_{3, \text { in }}-\mathrm{O}_{3, \text { out }}}{\mathrm{V}_{\mathrm{R}}} \mathrm{dt}
$$

where $\mathrm{O}_{3 \text {,trans }}$ denotes the ozone transferred $\left[\mathrm{g} . \mathrm{l}^{-1}\right], \mathrm{Q}_{\mathrm{g}}$ the gas flow rate $\left[\mathrm{Nm}^{-3}\right.$. $\left.\mathrm{min}^{-1}\right], \mathrm{O}_{3, \text { in }}$ the ozone concentration in the gas at the inlet $\left[\mathrm{g} . \mathrm{Nm}^{-3}\right], \mathrm{O}_{3, \text { out }}$ the ozone concentration in the gas at the outlet [g. $\mathrm{Nm}^{-3}$ ] and $\mathrm{V}_{\mathrm{R}}$ is the volume of the reactor [1].

\subsection{Ozonation of 2-mercaptobenzothiazole}

Ozonation trial with model wastewater containing 6.6 mmol.1-1 of 2-Mercaptobenzothiazole (MBT) was performed in a bubble ozonation column at the oxygen flow Q $\mathrm{O} 2=301 . \mathrm{h}^{-1}$. Performance of the ozone generator was maintained at $80 \%$ of the maximum value. Ozone concentration in the influent gas was $99.4 \mathrm{~g} . \mathrm{Nm}^{-3}$. Transferred ozone followed linear dependence on the reaction time $\left(R^{2}=0.9997\right)$. Average rate of ozone transfer was app. 3.0 g.h-1. 
Fig. 4 illustrates the decline of MBT and the evolution of Benzothiazole (BT) and Bezothiazole-2-sulfonate (BTS) as well as the time course of the sum of identified derivatives during ozonation of model wastewater containing MBT.

Total removal of MBT in 15 minutes of ozonation can be seen in this figure. Degradation of MBT followed the first order reaction rate (Eq. 2) with the reaction rate constant of $0.1365 \mathrm{~h}^{-1}$ $\left(R^{2}=0.9264\right)$. On the other hand, formation of intermediates, mainly BT and BTS, is evident from the figure. In addition to the BT derivatives presented in Fig. 4, the presence of Hydroxybezothiazole (OHBT) was observed with the maximum content after 10 minutes of ozonation and corresponded to about $4.0 \%$ of total BT derivatives at this stage of the trial. No presence of OHBT was observed after 30 minutes of ozonation. Only about $41.6 \%$ of organic carbon was oxidised (Eq. 5) during ozonation. About $40.3 \%$ of oxidised organic carbon was mineralised (Eq. 6) and the remaining 59.7\% of oxidised organics were only partially oxidised (Eq. 7).

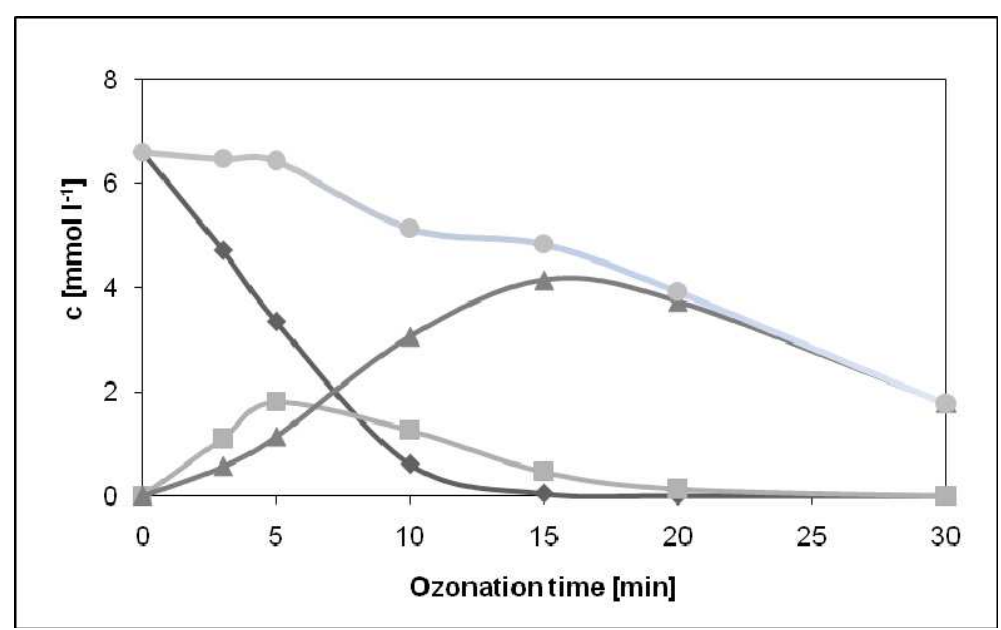

Fig. 4. Dependencies of BT derivatives' content on the ozonation time $\mathrm{MBT}, \boldsymbol{B T}, \boldsymbol{\Delta} \mathrm{BTS}, \bullet$ Sum of BT derivates

The presented results indicate that although the target pollutant was completely removed, intermediates and final oxidation products should be analysed with regard to possible inhibition of subsequent biological processes or even direct discharge into the aquatic environment.

\subsection{Ozonation of benzothiazole}

The next set of ozonation trials was performed with model wastewater containing BT. Ozonation was carried out in the bubble ozonation column at the oxygen flow $\mathrm{Q}_{\mathrm{O} 2}=601 . \mathrm{h}^{-1}$. Performance of the ozone generator was maintained at $80 \%$ of its maximum value. Dependencies and efficiency of BT removal on the ozone supplied are plotted in Figure 5. 


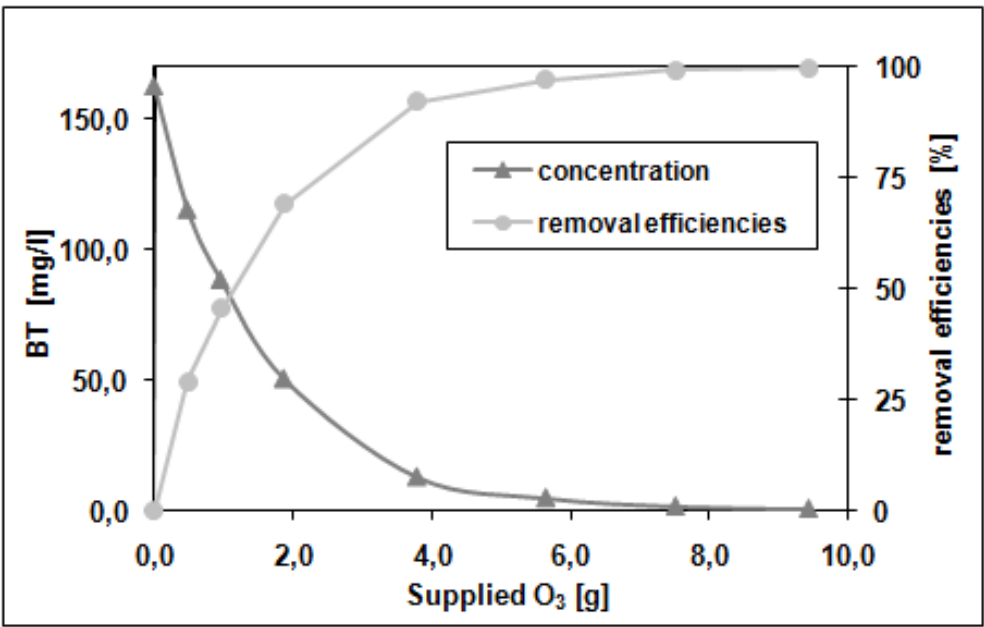

Fig. 5. BT removal dependencies on ozone supplied during ozonation of model wastewater

The concentration of BT dropped to 0.01 after 80 minutes of the process (about 8 g.l-1 of ozone supplied). The best fit of BT experimental data was obtained by the first-order kinetic model (Eq. 2) with the reaction rate constant of $6.1410^{-2} \mathrm{~h}^{-1}\left(\mathrm{R}^{2}=0.9989\right)$.

The time dependencies of COD and TOC removal during ozonation are presented in Figure 6.

The highest removals of TOC and COD were observed during the first 40 minutes of ozonation (ozone dose of app. 4.0 g.l-1). This corresponds also to the highest BT removal rate (Figure 5).

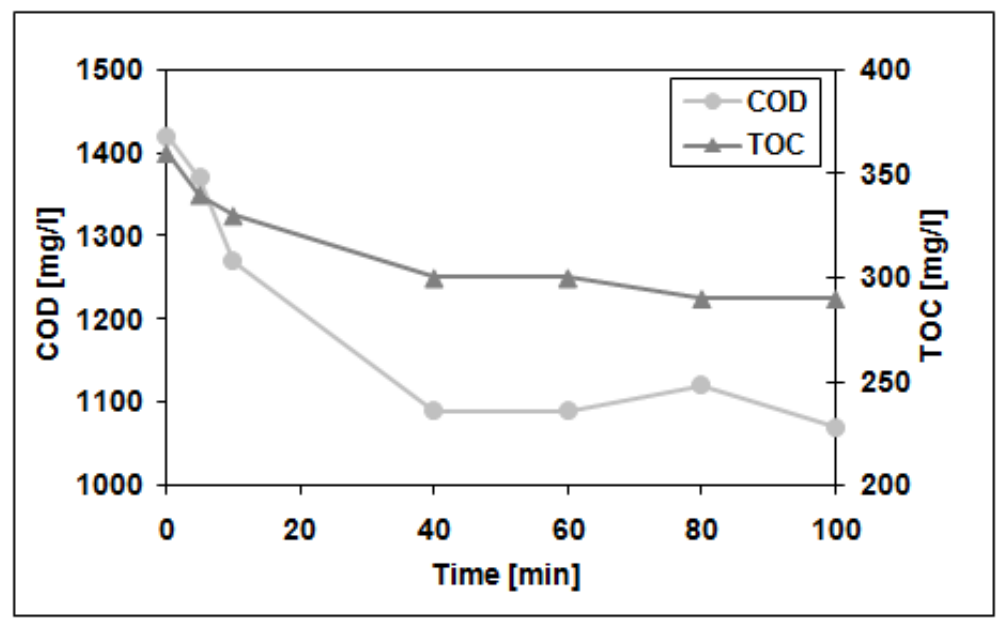

Fig. 6. COD and TOC removal dependencies on ozonation time 
On the other hand, the values of COD and TOC are too high when realising that the model wastewater contains only one component. Only about 25\% removal of TOC was observed (Eq. 5) during the process. About $70.9 \%$ of oxidised organic carbon was mineralised (Eq. 6) and the remaining $19.1 \%$ of oxidised organics were partially oxidised (Eq. 7).

The results of ozonation assay carried out in a completely mixed ozonation reactor with zeolite addition to synthetic wastewater containing BT are presented in this part.

Natural zeolitic tuff from the deposit in Nižný Hrabovec, Slovak Republic, with the granularity from 0.315 to $0.4 \mathrm{~mm}$ was used. This type of zeolite consists mostly of clinoptilolite (from 40 to $70 \%$ ), quartz (2 to $5 \%$ ), $\alpha$ cristobalite (6 to $10 \%$ ), feldspar (8 to $10 \%$ ) and volcanic glass from 13 to $30 \%$ (Lukáč et al., 2005).

The dependencies of BT concentration values and the efficiency of its removal as a function of zeolite dose are plotted in Figure 7. Ozonation time was 30 minutes and performance of ozone generator was $50 \%$ of its maximum power.

The efficiency of BT removal increased by $10 \%$ to $20 \%$ in the presence of zeolite in comparison with the ozonation of BT in its absence. However, variability of the zeolite dose did not influence the efficiency of BT removal significantly.

The influence of ozonation time on the BT removal efficiency is presented in Figure 8 . Performance of the ozone generator was maintained at $50 \%$ of the maximum power and $0.5 \mathrm{~g}$ of zeolite was applied in this set of experiments.

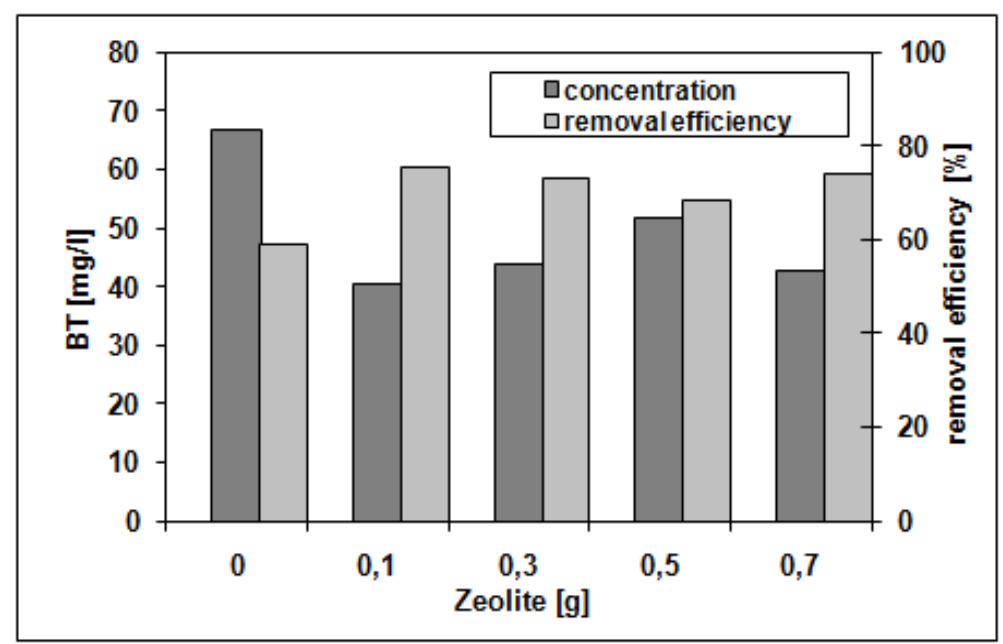

Fig. 7. Effect of zeolite dose on BT removal by ozonation

Significant positive influence of ozonation time on the efficiency of BT removal is obvious from Figure 8 . The efficiency of BT removal exceeded $96 \%$ after 60 minutes of the process. 


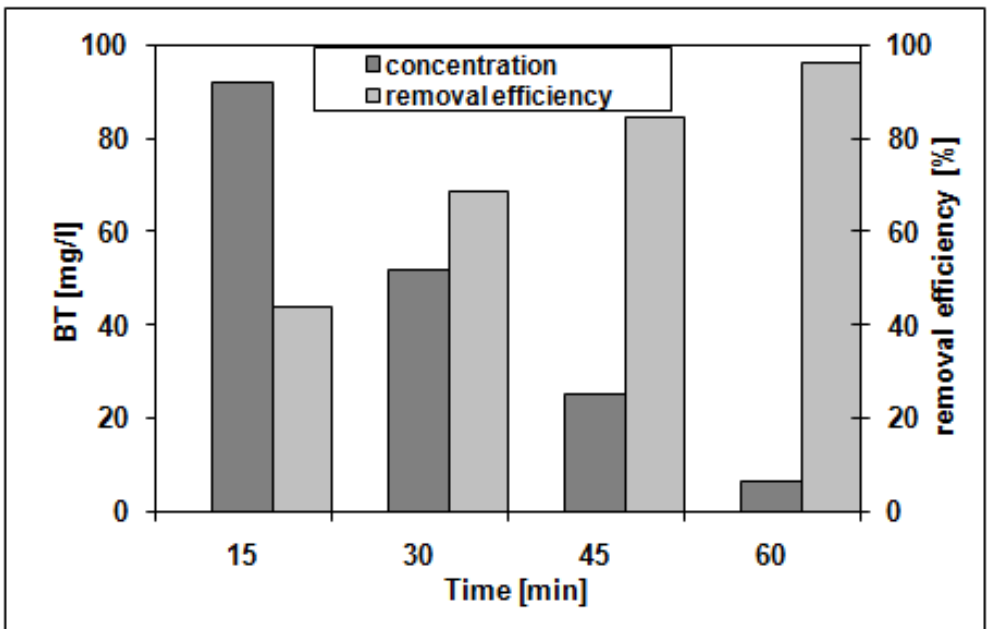

Fig. 8. Influence of ozonation time on BT removal efficiency

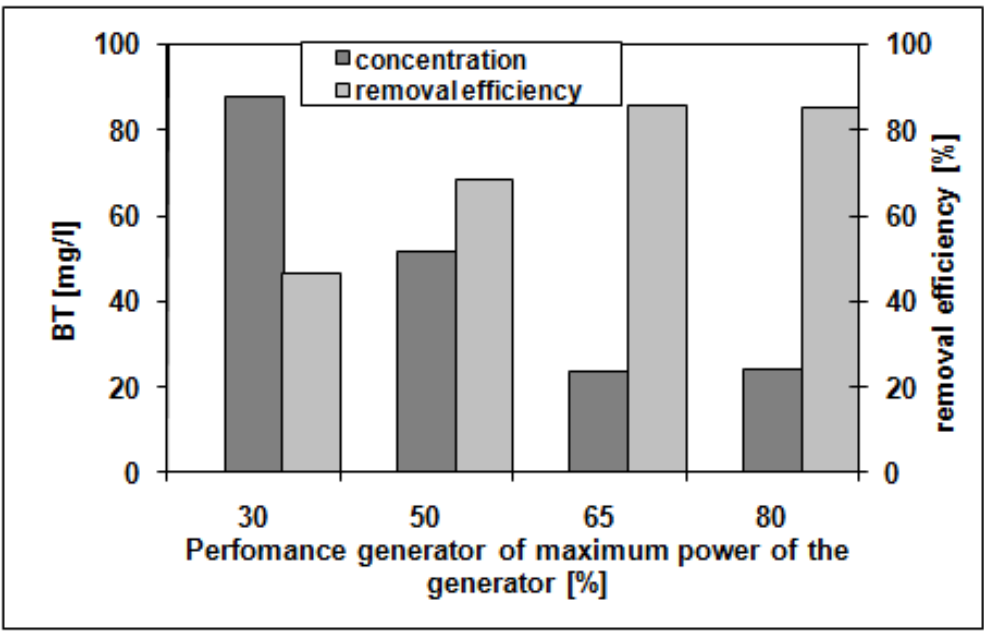

Fig. 9. Impact of ozone generator performance on removal efficiency of BT

On the other hand, the efficiency of BT removal increased by $20 \%$ in the presence of zeolite when comparing the results of both assays (Figures 7 and 9) performed at the ozone generator power of $50 \%$ of the maximum and 30 minutes of ozonation. As it can be seen from Figure 9, an increase of the ozone generator performance to over $65 \%$ of its maximum power did not lead to further increase of the BT removal efficiency.

The influence of the ozone generator performance on the BT removal in the presence of zeolite is presented in Figure 9. Ozonation time was $30 \mathrm{~min}$ and the dose of zeolite was $0.5 \mathrm{~g}$. The increase of the ozone generator power from 50 to $65 \%$ of its maximum power resulted in an increase of the BT removal efficiency by $18 \%$. 


\subsection{Ozonation of benzothiazole derivatives}

A mixture of BT and MBT was also treated. Ozonation was carried out in the bubble ozonation column at the oxygen flow $\mathrm{Q}_{\mathrm{O} 2}=601 . \mathrm{h}^{-1}$. Performance of the ozone generator was maintained at $80 \%$ of its maximum value.

MBT and BT removals during ozonation are presented in Figure 10. The $\mathrm{pH}$ value in the model wastewater containing BT and MBT was adjusted to 11.76 due to low solubility of MBT in water at lower $\mathrm{pH}$.

From Figure 10 it follows that the rate of MBT degradation is higher in comparison to the BT removal. The effectiveness of MBT removal was more than $99 \%$ after 10 minutes of ozonation. On the other hand, BT removal efficiency was only $21.5 \%$ after 10 minutes of the process. The decrease of COD (about 13\%) and TOC (about 7\%) was lower in comparison to the decrease of the BT and MBT content. Ozone dose with time was linear with ozonation time and was app. 0.1 g.min-1.

Kinetic parameter and correlation coefficients are given in Table 1. Time decline of MBT conformed to the first order kinetic model. The best fits of BT removal from the model wastewater containing BT and MBT was obtained with the kinetic model of the zero order (Table 1).

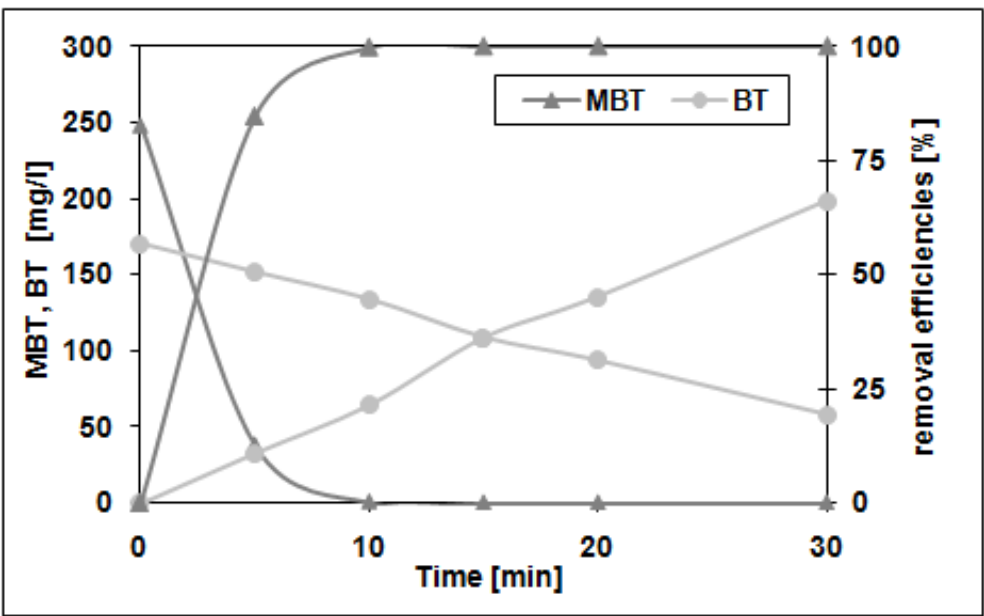

Fig. 10. BT and MBT removal during ozonation of model wastewater

\begin{tabular}{llll}
\hline \multirow{2}{*}{ Model } & $\begin{array}{l}\text { Parameter, objective } \\
\text { function }\end{array}$ & Removal of & \\
\cline { 3 - 4 } & $\mathrm{k}_{0} /\left(\mathrm{g} \mathrm{m}^{-3} \mathrm{~h}^{-1}\right)$ & & $\mathrm{MBT}$ \\
\hline Eq. (1) & $\mathrm{R}^{2}$ & & 3.8412 \\
& $\mathrm{k}_{1} / \mathrm{h}^{-1}$ & 0.382 & 0.9969 \\
Eq. (2) & $\mathrm{R}^{2}$ & 0.9994 & \\
&
\end{tabular}

Table 1. Kinetic parameters and correlation coefficients during ozonation of model wastewater containing BT and MBT 
Time dependencies of BT removal during ozonation of BT and BT/MBT model wastewaters are presented in Figure 11.

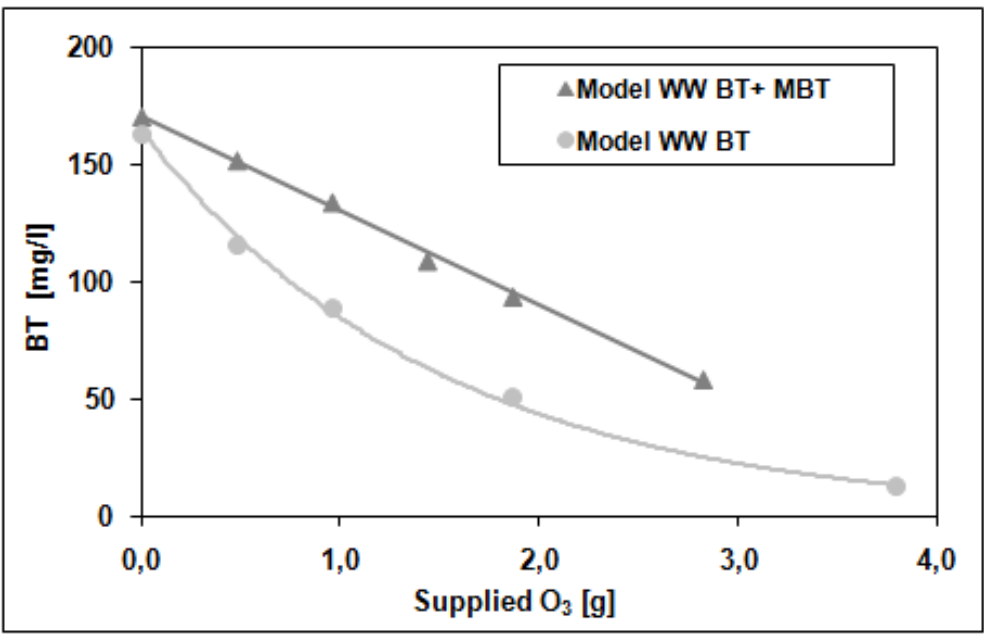

Fig. 11. BT removal during ozonation of model wastewaters

As it can be seen in Figure 11, kinetics of BT removal is lower during ozonation of the model wastewater containing BT and MBT (3.85 mg.l-1. min $\left.^{-1}\right)$ in comparison with BT model wastewater (5.60 mg.l-1. $\left.\mathrm{min}^{-1}\right)$. This can be explained by the transformation of MBT to BT (Figure 4) during ozonation.

The results of model wastewater ozonation containing MBT, BT, OHBT, 2Aminobenzthiazole (ABT), BTS and Aniline (AN), as the main organic pollutants of industrial wastewater produced in the production of N-cyclohexyl-2-benzothiazolsulfenamide, are presented in the next part. Brief characterisation of the industrial wastewater was reported by Derco at al. (2001). An ozonation jet loop reactor with external recirculation of the reaction mixture was applied in these experiments. As it was already mentioned, the mixture of oxygen and ozone was injected into a wastewater sample through a Venturi ejector. At the same time, the ejector sucked the gas mixture from the reactor headspace. This, together with external circulation, should improve the efficiency of ozone utilisation in the ozonation reactor.

Continuous flow of oxygen of $20 \mathrm{dm}^{3} \mathrm{~h}^{-1}$ was applied for the generation of ozone. Ozonation trials were carried out at $30 \%$ of the ozone generator's power maximum. External circulation of the reaction mixture was equal to the previous experiments performed in the jet loop reactor.

Dependencies of MBT, BT and BTS removal on the ozone supplied at $\mathrm{pH}=8.5$ and 5.8 are presented in Figure 12 and 13, respectively. 


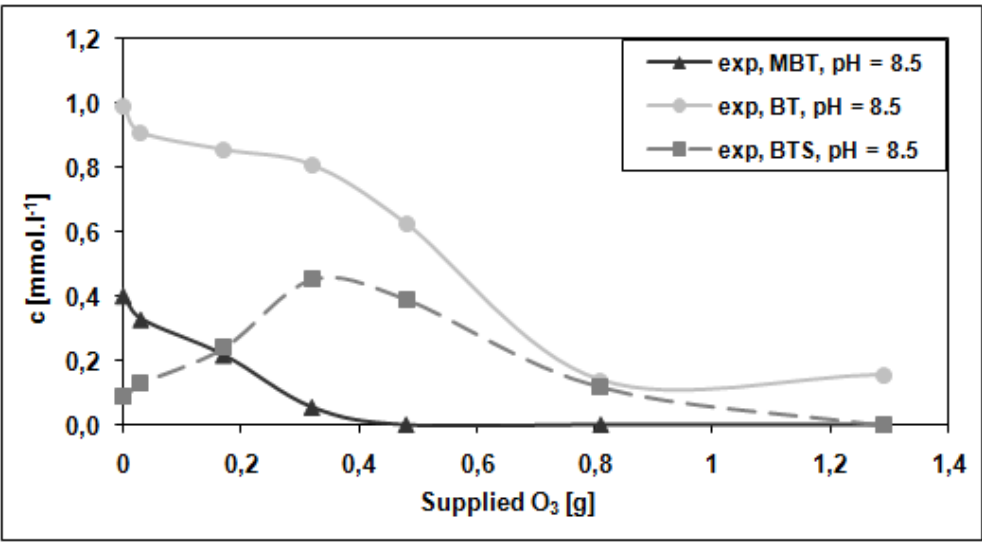

Fig. 12. Dependencies of MBT $(\boldsymbol{\Delta})$, BT $(\bullet)$ and BTS $(\boldsymbol{\bullet})$ removal on ozone supplied at pH 8.5

Higher removal rate of MBT was observed at higher $\mathrm{pH}$ value. A 99.5\% MBT removal efficiency was obtained after 40 minutes of the process $(0.48$ g.l-1 of ozone supplied/transferred). On the other hand, only a 75.7\% MBT removal efficiency was measured at lower $\mathrm{pH}$ value.

Significantly lower decline of BT content are obvious from Figures. 12 and 13. Only a 36.6\% BT removal efficiency at higher $\mathrm{pH}$ and a $0.97 \%$ BT removal efficiency at lower $\mathrm{pH}$ value were observed after 40 minutes of ozonation. However, removal rate of BT increases after the depletion of MBT and final observed removal efficiency at higher $\mathrm{pH}$ was $85.9 \%$. On the other hand, concentration of BTS increases with the decline of MBT and decreases after the MBT removal (Figure 13), i.e. maximum BTS concentration corresponds to minimum MBT concentration.

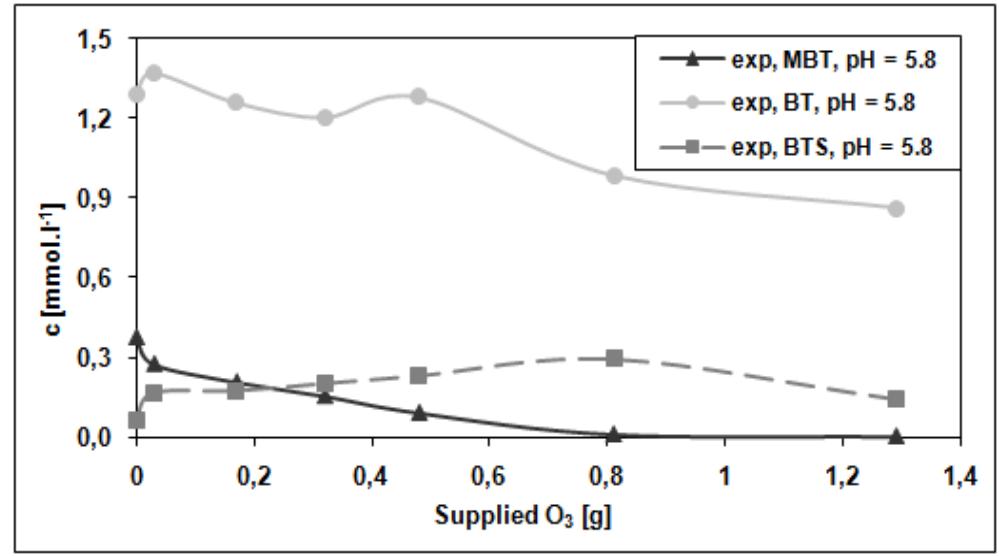

Fig. 13. Dependencies of MBT $(\mathbf{\Delta})$, BT $(\bullet)$ and BTS $(\mathbf{\bullet})$ removal on ozone supplied at pH 5.8

Higher $\mathrm{pH}$ value is favourable also for OHBT and ABT removals. Similarly to BT and BTS removals also removal rates of OHBT and ABT significantly increased after the MBT 
removal. The final observed removal efficiencies of OHBT and ABT were $87.5 \%$ and $84.9 \%$ respectively.

Results of the ozonation of industrial wastewater produced by the manufacture of sulphenamides are presented in the next part. BT and MBT were the main pollutants; $\mathrm{OHBT}, \mathrm{ABT}, \mathrm{MBT}$ and $\mathrm{AN}$ were also present in the investigated wastewater.

The ozonation jet loop reactor with external recirculation of the reaction mixture was applied also in these experiments. Continuous flow of oxygen of $601 . \mathrm{h}^{-1}$ was applied for the generation of ozone. Ozonation trials were carried out at $30 \%$ of the ozone generator's power maximum. External circulation of the reaction mixture was maintained at $0.51 . \mathrm{min}^{-1}$ by a membrane pump.

MBT removal dependencies on the ozonation time at different $\mathrm{pH}$ values are presented in Figure 14. The best fit of MBT experimental data was obtained by the second order kinetic model. The rate constant values and the values of $S_{r}^{2}$ relevant to the results of the MBT removal obtained by this model are given in Tables 2 and 3 .

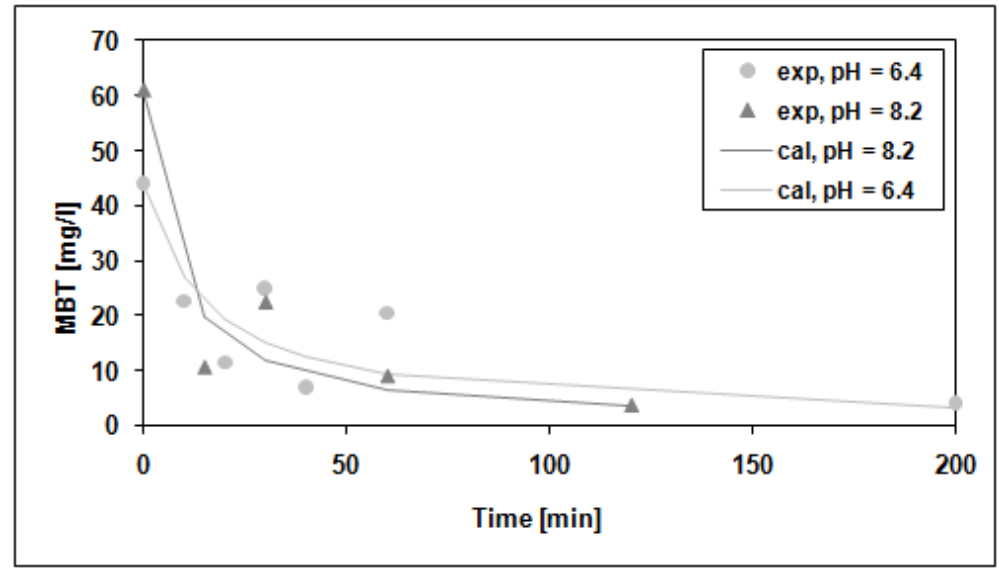

Fig. 14. MBT concentration removal during ozonation of wastewater samples at different $\mathrm{pH}$

The highest removal rate of MBT with ozone was observed during the first $10-15$ min of ozonation. Corresponding transferred ozone was 0.38 to $0.55 \mathrm{~g} \cdot \mathrm{l}^{-1} \mathrm{O}_{3}$. The conversion of MBT reached about $60 \%$ to $83 \%$ after this period of ozonation.

\begin{tabular}{ccccc}
\hline \multirow{2}{*}{ Model } & $\begin{array}{c}\text { Parameter, objective } \\
\text { function }\end{array}$ & MBT & Removal of \\
\cline { 2 - 5 } & $\mathrm{k}_{1} / \mathrm{h}^{-1}$ & - & - & $\mathrm{BN}$ \\
\hline Eq. (2) & $\mathrm{S}_{\mathrm{r}}^{2}$ & - & - & $5.0 \times 10^{-2}$ \\
& $\mathrm{k}_{2} /\left(\mathrm{g} \mathrm{m}^{-3} \mathrm{~h}^{-1}\right)$ & $1.4 \times 10^{-3}$ & $4.0 \times 10^{-5}$ & - \\
Eq. (3) & $\mathrm{S}_{\mathrm{r}}^{2}$ & $6.7 \times 10^{1}$ & $3.5 \times 10^{2}$ & - \\
& &
\end{tabular}

Table 2. Kinetic parameters and statistical values - ozonation at $\mathrm{pH}=6.4$ 
Figure 15 shows the time courses of BT removal during ozonation of wastewater samples performed at different $\mathrm{pH}$ values. Similarly to MBT, the best description of experimental data for BT removal was obtained by the second order kinetic model. The values of kinetic parameters and relevant $S_{r}^{2}$ for the BT experimental data obtained by the applied kinetic model are also summarised in Tables 2 and 3.

\begin{tabular}{ccccc}
\hline \multirow{2}{*}{ Model } & $\begin{array}{c}\text { Parameter, objective } \\
\text { function }\end{array}$ & MBT & Removal of \\
\cline { 2 - 4 } & $\mathrm{k}_{1} / \mathrm{h}^{-1}$ & - & - & $\mathrm{BN}$ \\
\hline Eq. (2) & $\mathrm{S}_{\mathrm{r}}^{2}$ & - & - & $7.3 \times 10^{-2}$ \\
& $\mathrm{k}_{2} /\left(\mathrm{g} \mathrm{m}^{-3} \mathrm{~h}^{-1}\right)$ & $2.3 \times 10^{-3}$ & $7.6 \times 10^{-5}$ & - \\
Eq. (3) & $\mathrm{S}_{\mathrm{r}}^{2}$ & $6.8 \times 10^{2}$ & $1.8 \times 10^{-1}$ & - \\
& & & & \\
\hline
\end{tabular}

Table 3. Kinetic parameters and statistical values - ozonation at $\mathrm{pH}=8.2$

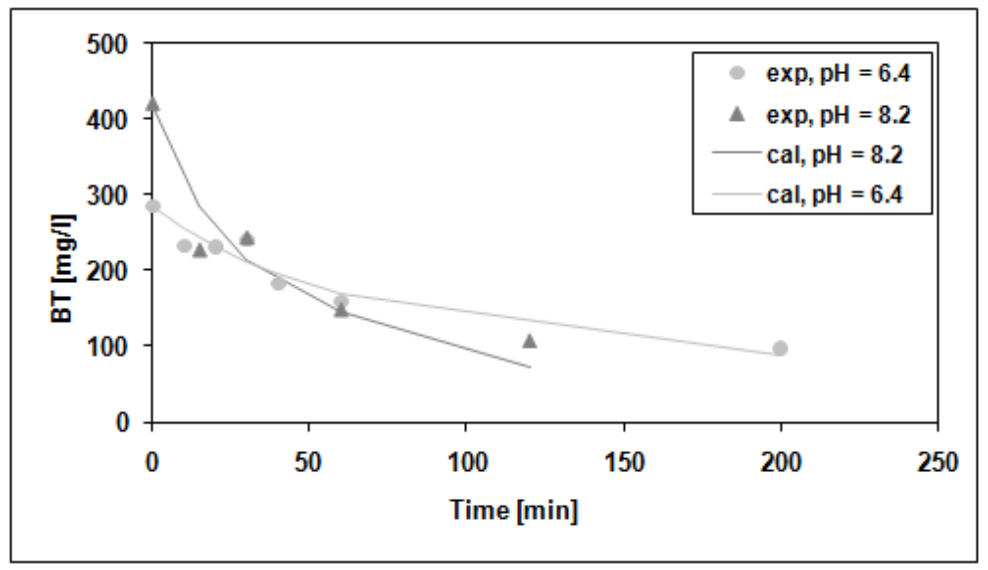

Fig. 15. BT removal during ozonation of wastewater samples at different $\mathrm{pH}$

Efficiency of the BT removal achieved about $19 \%$ to $46 \%$ after the above mentioned period of ozonation. Higher value of $\mathrm{pH}$ was more favourable both for MBT and BT removal.

Similar results were presented by Valdés et al. (2003) who investigated the importance of pH for indirect reactions of ozone with BT. According to their results, the influence of $\mathrm{pH}$ on the reaction rate is significant particularly at low $\mathrm{pH}$ values. However, only small differences in the $\mathrm{BT}$ removal carried out at $\mathrm{pH}=7$ and $\mathrm{pH}=9$ were observed by the authors.

Very fast decline of the AN content, with the treatment efficiency of above $90 \%$, was also achieved at this stage of the process (Figure 16). Slightly higher removal efficiency rate of AN was observed also at higher $\mathrm{pH}$ value with an about $68 \%$ removal efficiency during the first 15 minutes of ozonation. The final observed treatment efficiency of aniline was about $99 \%$. The AN experimental data conformed to the first order kinetic model. The statistical and kinetic parameter values are summarised in Tables 2 and 3. 


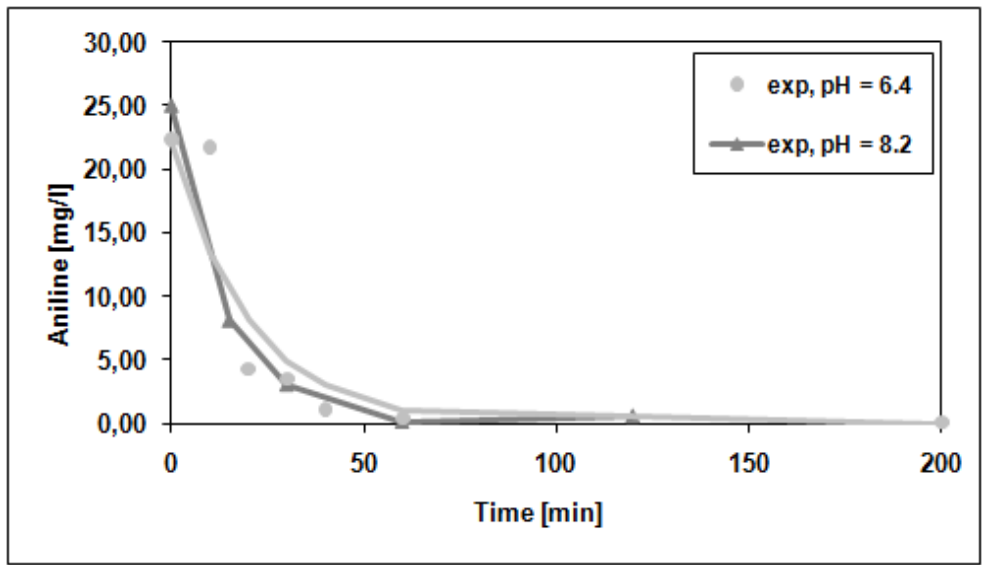

Fig. 16. Aniline removal dependencies on the reaction time during ozonation of wastewater samples at different $\mathrm{pH}$

Concentration values of $\mathrm{ABT}$ and $\mathrm{OHBT}$ remained more or less stable during the ozonation trials but their concentrations were lower by more than one order in comparison with the previous compounds.

COD removals during ozonation performed at different $\mathrm{pH}$ are presented in Figure 17. It is obvious that the removal efficiencies of organics are significantly lower when compared with those of individual organic pollutants (Figures 14 to 16). However, the highest COD removal was observed within the first 15 - 20 minutes of ozonation (transferred ozone 0.38 to 0.55 g. $1^{-1} \mathrm{O}_{3}$ ) similarly to other monitored pollutants.

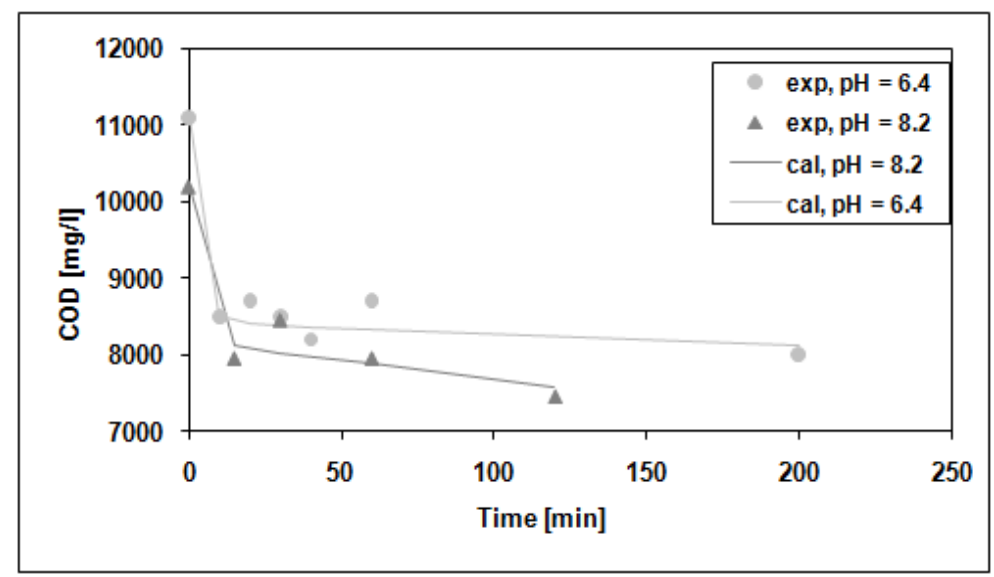

Fig. 17. COD removal dependencies on the reaction time during ozonation of wastewater samples at different $\mathrm{pH}$

Slightly higher removal rate of COD was observed at the lower $\mathrm{pH}$ value. Kinetics of COD removal follows the 'two components' model (Eq. 4) with a $24 \%$ portion of easily oxidizable 
compounds in the wastewater at the lower $\mathrm{pH}$ value $\left(\mathrm{k}_{\mathrm{EO}}=0.32 \mathrm{~h}^{-1}, \mathrm{k}_{\mathrm{SO}}=1.7810^{-4} \mathrm{~h}^{-1}\right.$, $\left.\mathrm{R}^{2}=0.9562\right)$.

Figures 18 and 19 show the portions of partially oxidised COD versus mineralised COD measured during ozonation at both $\mathrm{pH}$ values.

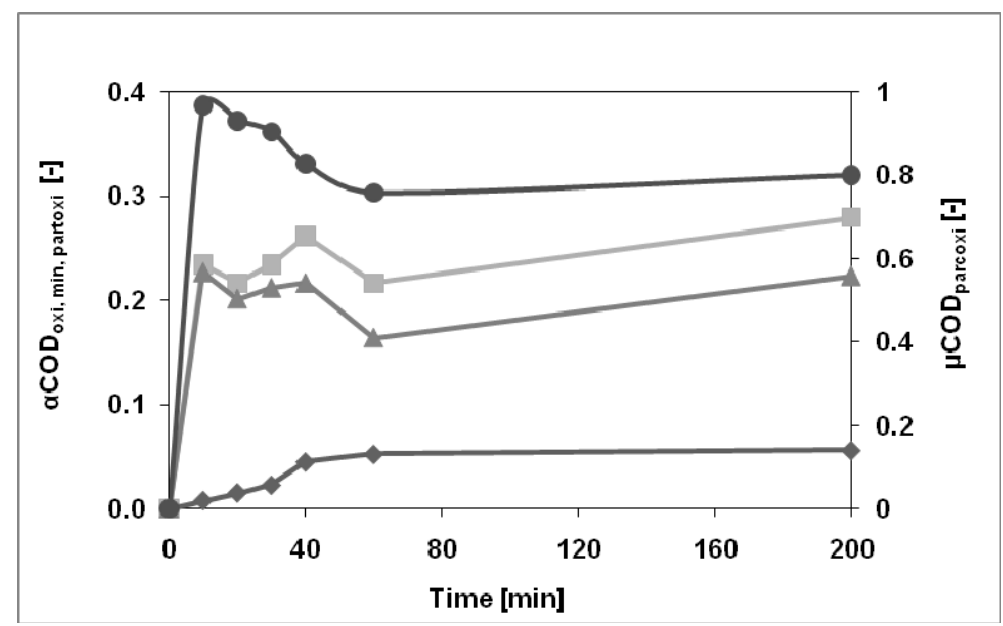

Fig. 18. Influence of ozonation time ( $\mathrm{pH}$ 6.4) on COD partial oxidation and mineralisation $\left(\boldsymbol{-} \operatorname{aCOD}_{\text {oxi, }}(\boldsymbol{\Delta}) \mathrm{aCOD}_{\text {min, }}(\bullet) \operatorname{aCOD}_{\text {parcoxi, }}(\bullet) \mu \mathrm{COD}_{\text {parcoxi }}\right.$

It is obvious that the highest degree and efficiency of partial oxidation was achieved within 10 to 15 minutes of ozonation at both $\mathrm{pH}$ values. However, the lower $\mathrm{pH}$ value is more favourable for partial oxidation.

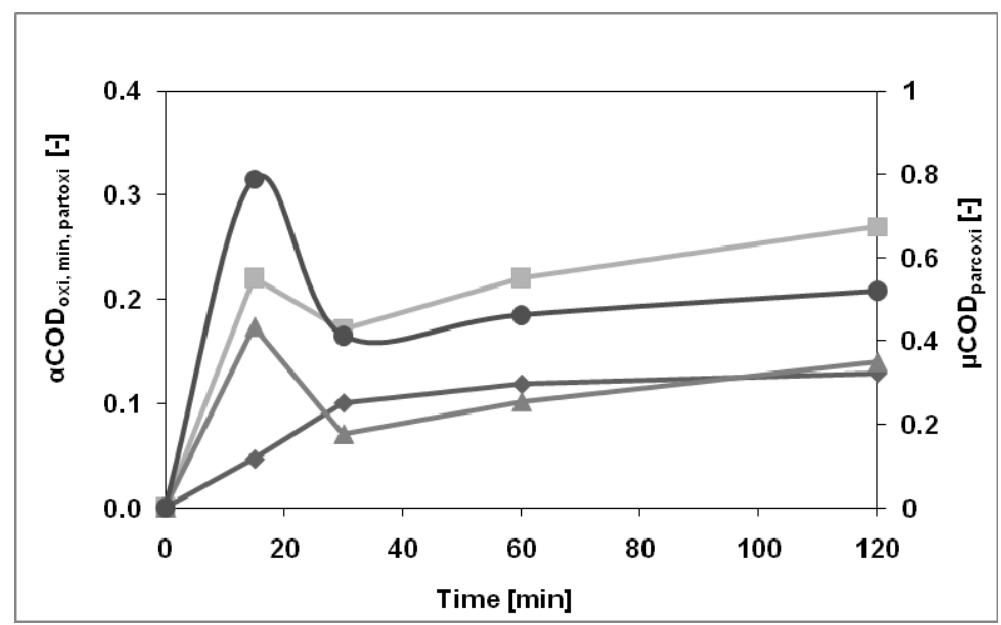

Fig. 19. Influence of ozonation time ( $\mathrm{pH}$ 8.2) on COD partial oxidation and mineralisation $(\boldsymbol{\bullet}) \mathrm{aCOD}_{\text {oxi, }}(\boldsymbol{\Delta}) \mathrm{aCOD}_{\min ,}(\bullet) \mathrm{aCOD}_{\text {parcoxi, }}(\bullet) \mu \mathrm{COD}_{\text {parcoxi }}$ 
Batch kinetic tests were performed with raw and ozonated wastewater samples and nonacclimated activated sludge sampled from a refinery WWTP. From Figure 20 follows a higher BT removal efficiency for ozonated WW sample (70.8\%) in comparison with untreated wastewater sample (63.3\%).

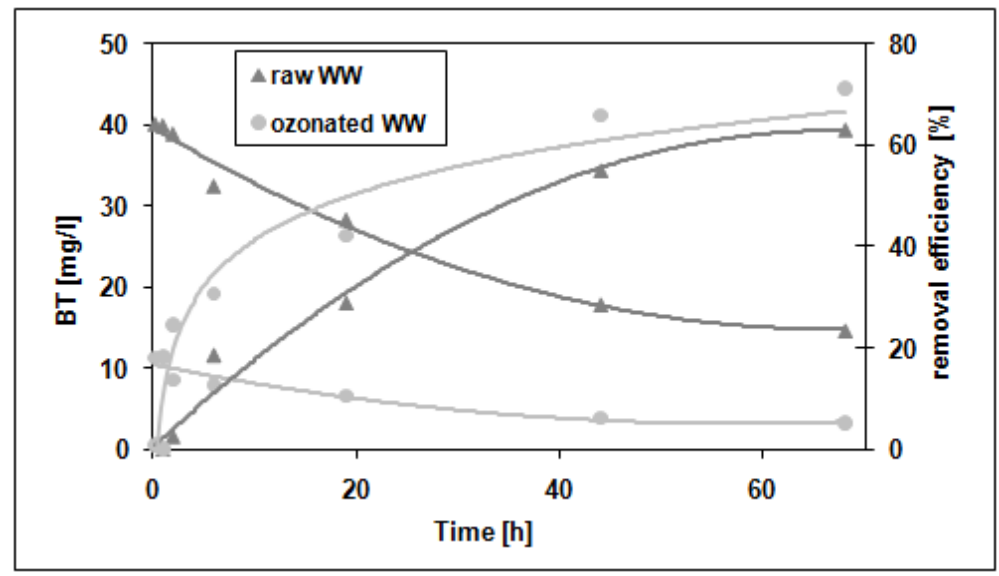

Fig. 20. BT removal during kinetic tests carried out using raw and ozonated wastewater

Complete removal of $\mathrm{AN}$ was observed in both the kinetic tests. The concentration values of $\mathrm{HOBT}$ and $\mathrm{ABT}$ were more or less constant during the tests.

Influence of the ozonated wastewater sample on the nitrification activity of activated sludge microorganisms was studied. Batch tests were carried out with activated sludge sampled from an industrial WWTP. Practically complete inhibition of the second nitrification step is characteristic for the applied activated sludge (Buday et al., 2000). Theis sample of industrial wastewater was used for reference measurements. Relatively low inhibition (up to $4.0 \%$ ) of the ozonated wastewater sample in the first nitrification step was observed.

\subsection{Integrated ozonation process}

An ozonation jet loop reactor with external circulation of the reaction mixture (Fig. 2) was used also for this set of experiments. Ozonation trials were carried out at the oxygen flow rate of $10 \mathrm{dm}^{3} \mathrm{~h}^{-1}$ and at $30 \%$ of the maximum ozone generator's power.

Results of the integrated processes of excess activated sludge solubilisation and simultaneous degradation of dissolved pollutants with ozone are presented in Figures 21 and 22 .

Cell membranes of the activated sludge are destroyed by ozone and the intercellular material is released into the liquid phase (Cui \& Jahng, 2004). Sludge ozonation is referenced 
as one of the most cost effective technologies with the highest disintegration capability (Múller, 2000; Park et al., 2003). Furthermore, ozonated sludge can be effectively utilised as an additional carbon source in a biological nitrogen removal process saving costs on an external carbon source (Ahn et al., 2002).

Impacts of non-ozonated and ozonated (20 min of ozonation) samples of MBT on the specific oxygen uptake rate of activated sludge microorganisms are presented in Fig. 21. Respirometric measurements were performed according to Spanjer et al (2000).

It is obvious, from the results, that untreated MBT exhibits an inhibition effect on the specific oxygen uptake rate already at very low concentration values in terms of COD. On the other hand, after 10 minutes of ozonation, the sample showed a stimulating effect on the respiration activities of activated sludge microorganisms oxygen uptake of up to 50 mg. $1^{-1}$ of organics in the COD term. Efficiency of the MBT removal was $85.5 \%$ after 20 minutes of ozonation.

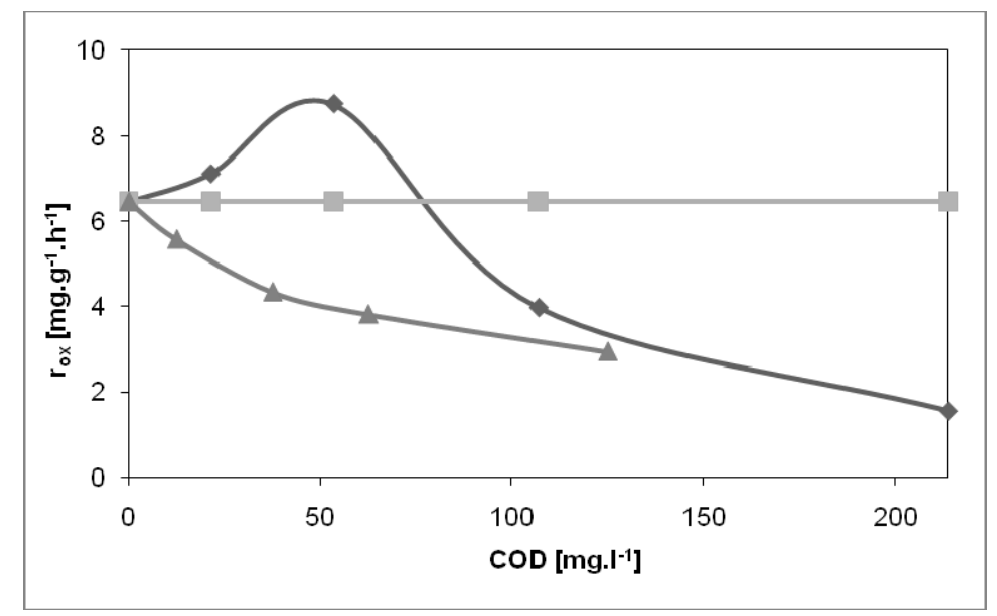

Fig. 21. Influence of ozonated (20 $\mathrm{min}$ ) and non-ozonated MBT on the oxygen uptake rate

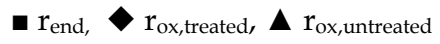

Influence of the liquid part of solubilised activated sludge by ozone performed in the presence of MBT on the specific oxygen uptake rate of activated sludge microorganisms is presented in Figure 22.

Removal efficiency of MBT after 20 minutes of ozonation of the mixture of activated sludge and MBT was 99\%. MBT was completely removed from the reaction mixture after 60 minutes of ozonation. Although the efficiencies of the MBT removal are very close for the 20 and 60 minutes ozonation, the impact of these ozonated samples on the respiration activity of activated sludge microorganisms is significantly different. 


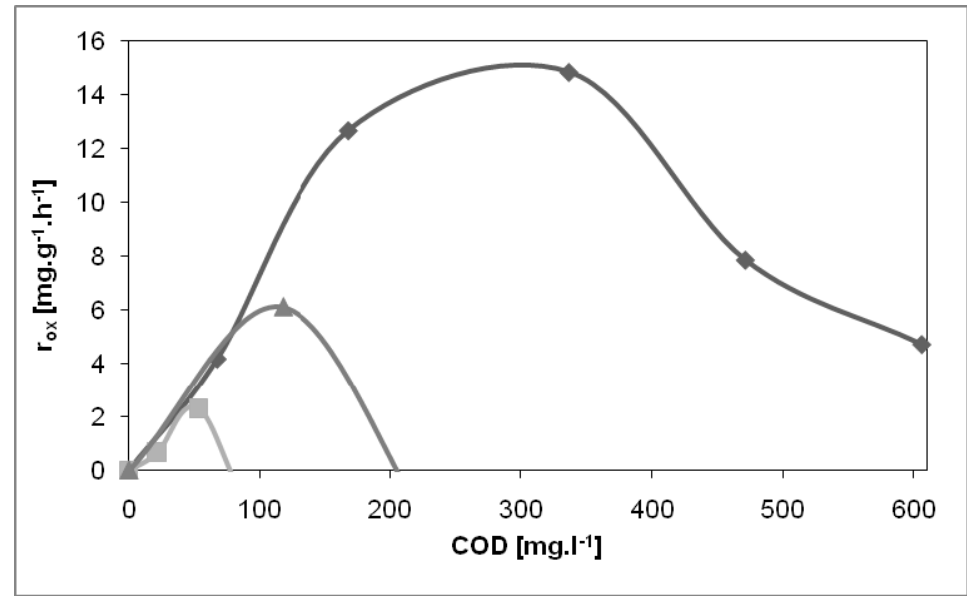

Fig. 22. Influence of ozonated AS and/or MBT on the oxygen uptake

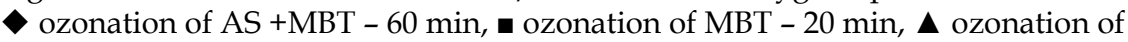
$\mathrm{AS}+\mathrm{MBT}-20 \mathrm{~min}$

\section{Conclusions}

Each of the various physical, chemical and biological processes developed for wastewater treatment has its own limitations in its applicability, effectiveness or cost.

Ozone is a very powerful oxidising agent that can react with most species containing multiple bonds, but not with singly bounded compounds at high rates. At lower $\mathrm{pH}$, direct selective oxidation predominates, while indirect reaction mechanisms dominate at higher $\mathrm{pH}$ values.

The main drawbacks of the ozonation process are relatively high operational costs related to the energy necessary for ozone preparation. Thus, ozonation alone is expensive in comparison with biological or some chemical oxidation processes due to the requirement of a high ozone dose needed for the complete degradation of organics. On the other hand, a very important advantage of ozone-based oxidation processes is that no chemical sludge is produced and thus there are no associated disposal costs in comparison with other chemical methods such as coagulation or precipitation.

Feasibility of the ozonation process to remove selected benzothiazols and the facilitation of subsequent biological wastewater treatment were studied. Results of ozonation trials carried out with the model wastewaters containing single MBT and BT pollutants, a mixture of BT and MBT, mixture of benzothiazole derivatives contained in an industrial wastewater from sulphenamides production and with real wastewater are presented. Total removal rate of MBT occurred within 10 to 15 minutes of ozonation (transferred $\mathrm{O}_{3}$ of app. 0.5 g.l-1) independently on the model wastewater composition. Formation of intermediates, mainly BT, BTS, and OHBT was observed. The best fit of MBT and BT experimental data was obtained by the first-order kinetic model for single model wastewater containing single pollutants. 
Lower removal rate of BT was observed in comparison with that of MBT, particularly in the presence of MBT. This can be explained by the transformation of MBT to BT (Figure 4) during ozonation. BT experimental data were well fitted by the zero-order kinetic model in this case.

Experimental results indicate that a combination of ozonation with zeolite enhances the BT removal efficiency and consequently enables a decrease of operational costs. BT removal efficiency increased by 10 to $20 \%$ in the presence of a zeolite.

Significant influence of MBT on the BT removal was observed when the model wastewater containing the main BT derivatives present in wastewater from sulphenamides production was ozonised. Removal rate of BT increased after the depletion of MBT. On the other hand, concentration of BTS increased with the decline of MBT and decreased after the MBT removal. Similarly to BT and BTS removals also removal rates of OHBT and ABT significantly increased after the MBT removal. Higher $\mathrm{pH}$ value was favourable for MBT, $\mathrm{BT}$, OHBT and ABT removals.

Higher $\mathrm{pH}$ value was also favourable for MBT and BT removal from the industrial wastewater. The best description of experimental data BT and MBT removal were obtained by the second order kinetic model. Concentration values of ABT and OHBT remained more or less stable during the ozonation trials but their concentrations were lower by more than one order in comparison to the previous compounds. The kinetics of COD removal follows the 'two components' model with a $24 \%$ portion of easily oxidizable compounds in wastewater at lower $\mathrm{pH}$. Similarly to COD, the lower $\mathrm{pH}$ value is more favourable also for partial oxidation.

The combination of ozonation as a pre-treatment process followed by biological oxidation integrates the benefit of low cost of biological treatment with that of ozonation. The aim of controlled ozonation is only partial oxidation of low-biodegradable complex organics. Higher BT removal efficiency for ozonated wastewater sample than for an untreated one was observed in a batch kinetic test. Relatively low inhibition of the ozonated wastewater sample in the first nitrification step was observed.

Ozonation might not always be able to enhance the biodegradability of complex industrial wastewaters. Experimental results of benzothiazole derivative degradation by ozone confirm the necessity of evaluating the effect of ozone on the characteristics of real complex wastewater in order to determine the appropriate ozonation conditions. Experimental results illustrate that prolonged ozonation time significantly decreases toxicity and enhances biodegradability by a continuing transformation of the initial intermediates of the ozonation process.

The results indicate that another possibility of improving the cost efficiency of the ozonation process is to integrate treatment targets, e.g. excess activated sludge minimisation simultaneously with the degradation and removal of micropollutants.

\section{References}

Ahn K. H., Yeom I. T., Park K. Y. Maeng S. K., Lee Y. H. \& Song K. G., (2002). Reduction of sludge by ozone treatment and production of carbon source for denitrification. Wat Sci. Technol. 46, (11-12) pp. 121-125. 
Boncz M. A., Bruning H. \& Rulkens, W. H., (2003). Innovative reactor technology for selective oxidation of toxic organic pollutants in wastewater by ozone. Water Science and Technology 47, (10) pp. 17-24.

Buday J., Halász L., Drtil M., Bodík I., Németh P. \& Buday M., (2000). Nitrogen removal from wastewater of chemical company Duslo. Wat. Sci. Tech., 41, (9) pp. 259-264.

Cui R. \& Jahng D., (2004). Nitrogen control in AO process with recirculation of solubilized excess sludge. Water Res. 38, pp. 1159-1172.

de Wewer H. \& Verachter H., (1997). Biodegradation and toxicity of benzothiazoles. Wat. Res. 31 (1997), pp. 2673-2684.

de Wewer H., Weiss S., Reemtsma T., Muller J., Knepper T., Rorden O. , Gonzalez S., Barcelo D. \& Hernando M. D., (2007). Comparison of sulphonated and other micropollutants removal in membrane bioreactor and conventional wastewater treatment. Wat. Res. 41, pp. 935-945.

Derco J., Gulyásová A., Králik M. \& Mrafková L., (2001). Treatment of an industrial wastewater by ozonation. Petroleum and Coal, 43 (2) 92-97.

Fanchiang J.-M., Tseng D.-H., Guo G.-L. \& Chen H-J., (2008). Ozonation of complex industrial park wastewater: effects on the change of wastewater characteristics. J. Chem. Technol. Biotechnol. 84, pp. 1007-1014.

Fiehn O., Wegener G., Jochimsen J. \& Jekel M., (1998). Analysis of the ozonation of 2mercaptobenzothiazole in water and tannery wastewater using sum parameters, liquid- and gas chromatography and capillary electrophoresis. Wat. Res., 32, pp. 1075-1084.

Fujita H., Izumi Y., Sagehashi M., Fuji T. \& Sakoda A., (2004). Adsorption and decomposition of water-dissolved ozone on high silica zeolites. Water Research, 38, 159-165.

Gaja M. A. \& Knapp J. S., (1998). Removal of 2-mercaptobenythiazole by activated sludge: a cautionary note. Wat. Res. 32, pp. $3786-3789$.

Gogate P. R. \& Pandit A. B., (2004). A review of imperative technologies for wastewater treatment I: oxidation technologies at ambient conditions. Advances in Environmental Research 8, pp. 501-551.

Greenberg A. E., Clesceri L. S. \& Eaton A. Eds., (2005). Standard Methods for the Examination of Water and Wastewater. 22nd Edition. Washington, DC.: American Public Health Association.

Hauck R. D., (1972). Synthetic slow release fertilizers and fertilizer amendments, pp 633-690. In Organic Chemicals in the Soil Environment. Edited by Goring C. A. I. and Hamaker J. W.

Hoigné J., Bader H., (1986). Determination of ozone and chlorine dioxine in water by the indigo method, analytical aspects of ozone treatment of water and wastewater. Lewis Publisher, Michigan.

ISO 6060, (1989). Water quality - Determination of chemical oxygen demand. Geneve, Switzerland: International Organisation for Standardisation. 1989.

Knapp J. S., Callez A. G. \& Minpriye J., (1982). The microbial degradation of morpholine. J. Appl. Bacteriol., 40, pp. 5-13. 
Kralchevska R., Premru, A., Tišler T., Milanova, M., Todorovsky D. \& Pintar A., (2010). UVand visible-light assisted photocatalytic oxidation of a pesticide over $\mathrm{TiO}_{2}$ catalysts modified with neodymium and nitrogen. In CD ROM of Full Texts of $7^{\text {th }}$ European Congress of Chemical Engineering ECCE and 19th International Congress of Chemical and Process Engineering CHISA 2010, 28 August - 1 September 2010, Prague, Czech Republic.

Lukač P., Földesová M. \& Svetlík Š., (2005). Synergistic effect of chemical and thermical treatment on the structure and sorption properties of natural and chemically modified Slovak zeolite. Petroleum \& Coal 47, (1) pp. 17-21.

Mujeriego R \& Asano, T., (1999). The role of advanced treatment in wastewater reclamation and reuse. Water Science and Technology 40, (4-5) pp. 1-9.

Múller J. A., (2000). Pretreatment processes for the recycling and reuse of sewage sludge. Water Sci. Technol. 42, (9) pp. 167-174.

Munter R., (2001). Advanced oxidation processes - current status and prospects. Proc. Estonian Acad. Sci. Chem. 50, (2) pp. 59-80.

Oller I., Sirtori C., Klamerth N. \& Zapata A., (2009). Decontamination of industrial wastewater by advanced oxidation processes coupled with biotreatment. In. Proceedings from INNOVA-MED Conference. Innovative processes and practices for wastewater treatment and re-use in the Mediterranean region. 8.-9 October 2009, Chirona, Spain. pp. 57-60.

Park K. Y., Ahn K. H., Maeng S. K., Hwang J. H. \& Kwon J. H., (2003). Feasibility of sludge ozonation for stabilisation and conditioning. Ozone Sci. Eng. 25 (1) pp. 73-80.

Poyotos J. M., Muñio M. M., Almecija M. C., Torres J. C., Hontoria E. \& Osorio F., (2010). Advanced oxidation processes for wastewater treatment: state of the art. Water air soil pollut 205, pp. 187-204.

Rice R. G., (1997). Applications of ozone for industrial wastewater treatment - A review. Ozone Science and Engineering. 18, pp. 477-515.

Rodrígeus S. M., (2009). Advanced technologies for wastewater treatment. In. Proceedings from INNOVA-MED Conference. Innovative processes and practices for wastewater treatment and re-use in the Mediterranean region. 8.-9 October 2009, Chirona, Spain. pp. $18-22$.

Rulkens W., (2008). Increasing significance of advanced physical/chemical processes in the development and application of sustainable wastewater treatment systems. Frontiers of Environmental Science and Engineering in China 2 (4) pp. 385-396.

Spanjer H., Vanrolleghem P. A., Olson G. \& Dold P.L., (2000). Respirometry in Control of the Activated Sludge Process: Principles. IAWQ Scientific and Technical Report No. 7. J. W. Arrowsmith Ltd, Bristol, England.

Tomlinson T. G., Boon A. G., \& Trotman C. N. A., (1966) Inhibition of nitrification in the activated sludge process of sewage disposal. J. Appl. Bacteriol. 29 (2) pp. 266-291.

Valdés H. \& Zahor C. A., (2006). Ozonation of benzothiazole saturated-activated carbons: Influence of carbon chemical surface properties. J. Hazard Mater. B153, pp. 10421048. 
Valdes H., Farfán, V. J., Manoli, J. A. \& Zaror C. A., (2009). Catalytic ozone aqueous decomposition promoted by natural zeolite and volcanic sand. J. Hazard Mater. 165, pp. 915-922.

Valdés H., Murillo F. A., Manoli J.A. \& Zahor C. A., (2008). Heterogeneous catalytic ozonation of benzothiazole aqueous solution promoted by volcanic sand. J. Hazard Mater. 153, pp. 1036-1042. 


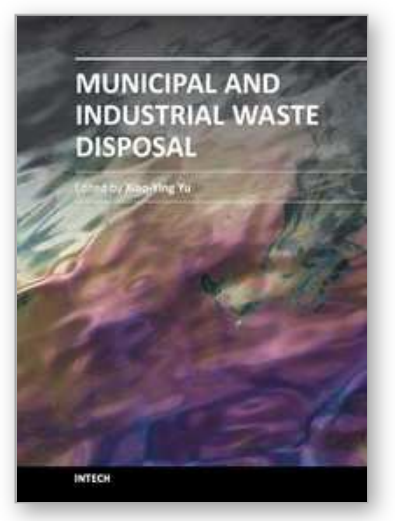

\author{
Municipal and Industrial Waste Disposal \\ Edited by Dr. Xiao-Ying Yu
}

ISBN 978-953-51-0501-5

Hard cover, 242 pages

Publisher InTech

Published online 11, April, 2012

Published in print edition April, 2012

This book reports research findings on several interesting topics in waste disposal including geophysical methods in site studies, municipal solid waste disposal site investigation, integrated study of contamination flow path at a waste disposal site, nuclear waste disposal, case studies of disposal of municipal wastes in different environments and locations, and emissions related to waste disposal.

\title{
How to reference
}

In order to correctly reference this scholarly work, feel free to copy and paste the following:

Jan Derco, Michal Melicher and Angelika Kassai (2012). Removal of Selected Benzothiazols with Ozone, Municipal and Industrial Waste Disposal, Dr. Xiao-Ying Yu (Ed.), ISBN: 978-953-51-0501-5, InTech, Available from: http://www.intechopen.com/books/municipal-and-industrial-waste-disposal/removal-of-selectedbenzothiazols-with-ozone

\section{INTECH}

open science | open minds

\author{
InTech Europe \\ University Campus STeP Ri \\ Slavka Krautzeka 83/A \\ 51000 Rijeka, Croatia \\ Phone: +385 (51) 770447 \\ Fax: +385 (51) 686166 \\ www.intechopen.com
}

\author{
InTech China \\ Unit 405, Office Block, Hotel Equatorial Shanghai \\ No.65, Yan An Road (West), Shanghai, 200040, China \\ 中国上海市延安西路65号上海国际贵都大饭店办公楼405单元 \\ Phone: +86-21-62489820 \\ Fax: +86-21-62489821
}


(C) 2012 The Author(s). Licensee IntechOpen. This is an open access article distributed under the terms of the Creative Commons Attribution 3.0 License, which permits unrestricted use, distribution, and reproduction in any medium, provided the original work is properly cited. 